\title{
Systematic Analysis of Cytostatic TGF-Beta Response in Mesenchymal-Like Hepatocellular Carcinoma Cell Lines
}

\author{
Medine Zeynep Gungor ${ }^{1,2} \cdot$ Merve Uysal $^{1,2} \cdot$ Mehmet Ozturk $^{1,3,4} \cdot$ Serif Senturk ${ }^{1,2,4}$
}

Accepted: 23 August 2021 / Published online: 31 August 2021

(c) Springer Science+Business Media, LLC, part of Springer Nature 2021

\begin{abstract}
Background Hepatocellular carcinoma (HCC) is one of the most challenging malignancies, with high morbidity and mortality rates. The transforming growth factor- $\beta$ (TGF- $\beta$ ) pathway plays a dual role in HCC, acting as both tumor suppressor and promoter. A thorough understanding of the mechanisms underlying its opposing functions is important. The growth suppressive effects of TGF- $\beta$ remain largely unknown for mesenchymal HCC cells. Using a systematic approach, here we assess the cytostatic TGF- $\beta$ responses and intracellular transduction of the canonical TGF- $\beta /$ Smad signaling cascade in mesenchymal-like HCC cell lines.

Methods Nine mesenchymal-like HCC cell lines, including SNU182, SNU387, SNU398, SNU423, SNU449, SNU475, Mahlavu, Focus, and Sk-Hep1, were used in this study. The cytostatic effects of TGF- $\beta$ were evaluated by cell cycle analysis, BrdU labeling, and SA- $\beta$-Gal assay. RT-PCR and western blot analysis were utilized to determine the mRNA and protein expression levels of TGF- $\beta$ signaling components and cytostatic genes. Immunoperoxidase staining and luciferase reporter assays were performed to comprehend the transduction of the canonical TGF- $\beta$ pathway.

Results We report that mesenchymal-like HCC cell lines are resistant to TGF- $\beta$-induced growth suppression. The vast majority of cell lines have an active canonical signaling from the cell membrane to the nucleus. Three cell lines had lost the expression of cytostatic effector genes.

Conclusion Our findings reveal that cytostatic TGF- $\beta$ responses have been selectively lost in mesenchymal-like HCC cell lines. Notably, their lack of responsiveness was not associated with a widespread impairment of TGF- $\beta$ signaling cascade. These cell lines may serve as valuable models for studying the molecular mechanisms underlying the loss of TGF- $\beta$-mediated cytostasis during hepatocarcinogenesis.
\end{abstract}

Keywords Hepatocellular carcinoma $\cdot$ TGF- $\beta$ pathway $\cdot$ Cytostatic response $\cdot$ HCC cell lines $\cdot$ Mesenchymal

Medine Zeynep Gungor and Merve Uysal contributed equally to this work.

Serif Senturk

serif.senturk@ibg.edu.tr

1 Izmir Biomedicine and Genome Center, Izmir 35340, Turkey

2 Department of Genome Sciences and Molecular Biotechnology, Izmir International Biomedicine and Genome Institute, Dokuz Eylul University, Izmir 35340, Turkey

3 Department of Medical Biology, Faculty of Medicine, Izmir Tinaztepe University, Izmir 35400, Turkey

4 Department of Molecular Biology and Genetics, Bilkent University, Ankara 06800, Turkey

\section{Introduction}

Liver cancer is the sixth most prevalent cancer worldwide, with 905,677 new cases diagnosed in 2020, and the third leading cause of cancer-related death. Hepatocellular carcinoma (HCC) is the most common type of liver cancer, accounting for nearly $90 \%$ of all occurrences [1]. Multiple risk factors have been related to the molecular etiology of HCC. Hepatocarcinogenesis is often associated with cirrhosis, an underlying liver disease characterized by prolonged inflammation owing to persistent infection with hepatitis B and $C$ virus, alcohol consumption, and aflatoxin $B 1$ exposure [2]. Nonalcoholic fatty liver disease, diabetes, and obesity have also been linked to HCC development [3]. The pathophysiology of HCC has been better understood thanks to the invention and advancement of high-throughput genomic 
technologies over the last two decades, allowing the identification and characterization of molecular mechanisms responsible for tumor initiation and progression. Evidence collected in recent genomic studies has revealed that HCC development is a multistep process associated with a variety of genetic and epigenetic alterations, which collectively culminate in dysregulation of various gene regulatory networks and intracellular signaling cascades [4, 5].

Hepatocellular carcinoma typically emanates as a welldifferentiated epithelial cancer and progresses through a continuous process of dedifferentiation into morphologically less differentiated advanced stages, a phenomenon that can be recapitulated in cell line models [6]. Particularly, HCC cell lines can be classified into epithelial-like and mesenchymallike subgroups based on their expression of epithelial and mesenchymal markers, respectively [7]. In essence, the epitheliallike HCC cells are phenotypically similar to hepatocytes and express hepato-specific genes, and hence referred to as hepatoblast-like cells, whereas the mesenchymal-like HCC cells are less differentiated with diminished expression of hepatocyte, and epithelial markers [8]. Within this framework, the epithelial-like and mesenchymal-like subgroups are frequently designated as well-differentiated and poorly differentiated, respectively. Finally, epithelial-like HCC cell lines are characterized by increased alpha-fetoprotein (AFP) expression, whereas the mesenchymal-like HCC cell lines are considered AFP-negative [7].

The transforming growth factor- $\beta$ (TGF- $\beta$ ) pathway is a multifunctional signaling cascade involved in the regulation and coordination of critical cellular processes, such as cell differentiation, apoptosis and proliferation, epithelial-tomesenchymal transition (EMT), and extracellular matrix formation [9]. The TGF- $\beta$ signaling occurs through a canonical and a non-canonical pathway, also known as Smad-dependent and Smad-independent, respectively [10]. The canonical TGF- $\beta$ signaling axis initiates at the cell membrane when one of the three TGF- $\beta$ ligands (TGF- $\beta 1$, TGF- $\beta 2$, TGF- $\beta 3$ ) binds to TGF $\beta$ receptor type 2 (TGF $\beta$-RII) and TGF $\beta$ receptor type 1 (TGF $\beta$-RI) serine-threonine kinase receptors, leading to the formation of a heterodimeric receptor complex and transphosphorylation of both receptors. The activated receptor complex recruits receptor-regulated Smads (R-Smads, Smad2 and Smad3) which act as substrates for TGF $\beta$-RI-mediated phosphorylation at their C-terminal serine residues [11]. After this phosphorylation, R-Smads form a transcriptional complex with the common-mediator Smad4 and accumulate in the nucleus. This complex then cooperates with different DNAbinding cofactors that define target selectivity, and recruit coactivators and corepressors to control the expression of several hundred target genes $[12,13]$.

The molecular role of TGF- $\beta$ signaling in HCC is highly context dependent, acting as a tumor suppressor in early phases of the malignancy before switching to a tumor promoter in later stages, underscoring its dual and opposing activities [14]. A key tumor suppressive axis of TGF- $\beta$ pathway is cytostasis, which refers to the inhibition of cell proliferation and cell cycle progression. Evidence from various sources suggest that the activation of TGF- $\beta$ can enforce cytostatic responses in in vitro and in vivo cancer models representing early disease states $[15,16]$. However, as tumors progress towards later stages, TGF- $\beta$ signaling facilitates cellular and molecular differentiation of cancer cells and reprogramming of the tumor microenvironment, resulting in progressive malignant transformation and aggressive phenotypes [17]. These effects are mediated in part by the activation of an EMT program, which permits cancer cells to acquire the ability to invade surrounding tissues, and spread to and grow at distant sites [17]. However, it is still unclear how TGF- $\beta$ signaling switches from a tumor inhibitor to a tumor enhancer. In line with this, yet another question to be addressed is whether cancer cells preferentially neutralize TGF- $\beta$-mediated cytostatic responses while maintaining others active, including EMT, migration, invasion, and immunosuppression.

As alluded to earlier, HCC cell lines can in principle mimic the biology of both the early and late stages of hepatocarcinogenesis [7]. By that means, they provide suitable experimental models for investigating the diversity of phenotype-specific cellular responses to TGF- $\beta$ treatment and elucidating the potential molecular mechanisms underlying the dual role of this pathway. The biological responses of TGF- $\beta$ have been extensively studied in several cell lines, most notably the epithelial-like HCC cell lines [18, 19]. One of those pioneering reports published by our group demonstrates that epithelial-like HCC cell lines entail an active TGF- $\beta$ signaling cascade and exhibit a robust cytostatic response characterized by cellular senescence [19]. Consistent with our report, the study by Coulouarn et al. characterized epithelial-like HCC cell lines by an early TGF- $\beta$ gene signature associated with TGF- $\beta$-induced cytostasis and apoptosis. Importantly, the same study identified mesenchymal-like HCC cell lines by a late TGF- $\beta$ gene signature associated with TGF- $\beta$-induced metastasis and EMT. They also exhibited distinct transcriptome profiles reminiscent of more invasive phenotypes and late-stage malignancy [20].

Despite its importance, the cytostatic response of mesenchymal-like HCC cell lines to TGF- $\beta$ has remained understudied. In this study, we systematically investigated the cytostatic TGF- $\beta$ responses of a large panel of mesenchymal-like HCC cell lines. To this end, we treated all cell lines with TGF- $\beta$ under similar conditions and performed cell cycle analysis and cellular senescence assay, and measured cell proliferation indexes via BrdU incorporation during DNA synthesis. Furthermore, we assessed the functionality of the canonical TGF- $\beta$ signaling cascade from the cell membrane to the nucleus. Finally, we studied the expression 
of common genes known to play an effector role in TGF$\beta$-induced cytostasis of epithelial-like HCC cell lines. Our results highlight that mesenchymal-like $\mathrm{HCC}$ cell lines have selectively lost the cytostatic TGF- $\beta$ responses without compromising the intactness of the signaling cascade, emphasizing their applicability, together with epitheliallike HCC cell lines, to study the molecular mechanisms of TGF- $\beta$-mediated cellular responses, including cytostasis, during hepatocarcinogenesis.

\section{Methods}

\section{Cell Culture}

Cell lines were maintained at $37^{\circ} \mathrm{C}$ and $5 \% \mathrm{CO}_{2}$ culture conditions. Furthermore, Huh7, Mahlavu, Focus, and Sk-Hep1 cells were cultured in Dulbecco's modified Eagle's medium (DMEM high glucose medium, Gibco). Medium was supplemented with $10 \%$ fetal bovine serum (FBS, Gibco) and $1 \%$ penicillin-streptomycin (Gibco). SNU182, SNU387, SNU398, SNU423, SNU449, and SNU475 cells were maintained in Roswell Park Memorial Institute Medium (RPMI 1640, Gibco) supplemented with 10\% FBS and 1\% penicillin-streptomycin.

For cryopreservation, cells grown in 10-cm dishes were trypsinized following a rinse with phosphate-buffered saline (PBS), and harvested with $5 \mathrm{ml}$ of RPMI or DMEM medium in a 15-ml Falcon tube. The harvested cells were centrifuged at $1800 \mathrm{rpm}$ for $2 \mathrm{~min}$ in a tabletop centrifuge. The pellet was then resuspended in a freezing medium prepared in the respective cell culture medium supplemented with $20 \%$ FBS and $8 \%$ DMSO and transferred to cryovial tubes which were kept at $-80^{\circ} \mathrm{C}$ freezer for short-term or liquid nitrogen for long-term storage. For thawing, one vial of frozen cells was retrieved from the $-80{ }^{\circ} \mathrm{C}$ freezer or nitrogen tank and was placed in a $37{ }^{\circ} \mathrm{C}$ water bath until only a small piece of ice was left in the vial. Thawed cells were then transferred into a 15-ml Falcon tube containing 9-ml growth medium and centrifuged in a tabletop centrifuge at $1800 \mathrm{rpm}$ for $2 \mathrm{~min}$. Then, the cell pellet was resuspended in complete growth medium and transferred to an appropriate cell culture dish. All experiments were performed within 1 month of thawing a cryopreserved vial of cells. All cell lines were routinely tested and confirmed negative for mycoplasma contamination Table 1.

\section{Bromodeoxyuridine (BrdU) Labeling and Detection}

Bromodeoxyuridine (5-Bromo-2'-Deoxyuridine, BrdU) labeling was performed to quantify the proliferation rate of TGF- $\beta$-treated cells. To this end, the cells were plated in duplicate on coverslips in 24-well cell culture plates and treated with $5 \mathrm{ng} / \mathrm{ml}$ of TGF- $\beta 1$ (hereafter referred to as TGF- $\beta$ ). Following 48-h incubation, medium was replaced with a freshly prepared culture medium containing TGF- $\beta$ and $\operatorname{BrdU}(30 \mu \mathrm{M})$, and the cells were labeled for $24 \mathrm{~h}$. To perform BrdU staining, the cells were fixed on ice for $10 \mathrm{~min}$ with $70 \%$ ice-cold ethanol, followed by an incubation with $2 \mathrm{~N} \mathrm{HCl}$ for $20 \mathrm{~min}$ to facilitate DNA denaturation. Next, the coverslips were incubated with mouse monoclonal antiBrdU antibody (Cell Signaling Technology) for $2 \mathrm{~h}$ at room temperature. After extensive washing with PBS, the coverslips were incubated with anti-mouse Alexa Fluor 488 (Abcam) for $1 \mathrm{~h}$. Finally, nuclear counterstaining with DAPI was performed for $1 \mathrm{~min}$ and the coverslips were mounted with an appropriate mounting medium and imaged under a fluorescence microscope. The percentage of proliferative cells was calculated as the number of BrdU-labeled cells over the total number of DAPI-stained nuclei counted in five random microscope fields (magnification, $200 \times$ ).

\section{Western Blotting}

The cells were collected with a cell-scraper and lysed with a modified Radio-Immunoprecipitation Assay (RIPA) Buffer (10 mM Tris-HCl, pH 7.6, 5 mM EDTA, $50 \mathrm{mM}$ $\mathrm{NaCl}, 30 \mathrm{mM}$ sodium pyrophosphate, $50 \mathrm{mM}$ sodium fluoride, $100 \mu \mathrm{M}$ sodium orthovanadate, $1 \%$ Triton $\mathrm{X}-100$, and $1 \times$ protease inhibitor complex). The concentrations of protein lysates were determined by the Bradford assay and standardized using a known concentration of bovine serum albumin (BSA). SDS-PAGE was performed with $25 \mu \mathrm{g}$ of total protein. Thereafter, the proteins were wet-transferred onto either HyBond ECL nitrocellulose (Amersham) or PVDF membrane (Bio-Rad). Depending on the antibodies used, the membranes were blocked for $1 \mathrm{~h}$ at room temperature with either $5 \%$ nonfat dry milk or $5 \%$ BSA in TBS-T (Tris-buffered saline supplemented with Tween 20). The primary antibodies were incubated for $1 \mathrm{~h}$ at room temperature or overnight at $+4{ }^{\circ} \mathrm{C}$. The secondary antibodies conjugated with horseradish peroxidase (HRP) were incubated for $1 \mathrm{~h}$ at room temperature. The chemiluminescent signals were developed using Pierce ECL Plus western blot detection reagents (Thermo Fisher Scientific), according to the manufacturer's instructions, and transferred to X-ray films (Amersham) Table 2.

\section{RNA Extraction and cDNA Synthesis}

Total RNA from cultured cells was extracted using NucleoSpin RNA II Kit (Macherey-Nagel), according to the manufacturer's protocol. The cDNA was synthesized with $2 \mu \mathrm{g}$ of DNaseI-treated total RNA using The RevertAid First Strand cDNA synthesis kit (Thermo Fisher Scientific) and stored at $-20^{\circ} \mathrm{C}$. Finally, relevant primers were designed 
and the expression of corresponding genes was assessed using semiquantitative reverse transcriptase PCR assay (RTPCR) Table 3.

\section{Semiquantitative RT-PCR Assays}

The PCR reactions were carried out as described previously [19]. Briefly, the reactions were set up in a total volume of $20 \mu \mathrm{l}$, with each sample receiving $2 \mu \mathrm{l}$ of cDNA. The reactions were started with a 5-min denaturation at $95{ }^{\circ} \mathrm{C}$, followed by 30 cycles of amplification $\left(30 \mathrm{~s}\right.$ at $95{ }^{\circ} \mathrm{C}, 30 \mathrm{~s}$ at $60{ }^{\circ} \mathrm{C}$, and $30 \mathrm{~s}$ at $72{ }^{\circ} \mathrm{C}$ ) and 5-min final extension at $72{ }^{\circ} \mathrm{C}$. GAPDH served as internal control (18 cycles of amplification). After the PCR, the amplicons were run on $2 \%$ agarose gel. The experiments were repeated three times.

\section{Immunoperoxidase Staining}

The cells were fixed with $4 \%$ formaldehyde diluted in PBS from $37 \%$ stock solution (Sigma), and permeabilized with $0.5 \%$ saponin (Sigma) and $0.3 \%$ Triton X-100 (Sigma) in PBS. Following the blocking step for $1 \mathrm{~h}$ (blocking solution, $10 \%$ FBS and $0.1 \%$ Triton X-100 in PBS), the cells were incubated with phospho-Smad3 (Ser423/425) antibody in PBS containing $2 \%$ FBS and $0.1 \%$ Triton X-100 solution for $1 \mathrm{~h}$. After extensive washing with PBS, the coverslips were incubated for 30 min with EnVision + Dual Link-HRP (Dako), followed by DAB detection solution (Dako) for a few minutes at room temperature. Finally, after being rinsed with purified water and counterstained with hematoxylin (Sigma) for 3-4 min, the coverslips were mounted on glass microscopic slides using $90 \%$ glycerol and visualized using a light microscope. The percentage of nuclear p-Smad3 staining was calculated as the number of p-Smad3-positive nuclei over the total number of hematoxylin-stained nuclei counted in four random microscope fields (magnification, 200×).

\section{Senescence-Associated Beta-Galactosidase (SA- $\beta$-Gal) Assay}

The cells were rinsed twice with PBS and fixed with $4 \%$ formaldehyde for $5 \mathrm{~min}$ at room temperature. After two additional washes with PBS, SA- $\beta$-Gal staining solution $(40 \mathrm{mM}$ citric acid/Na phosphate buffer, $5 \mathrm{mM}$ potassium ferrocyanide, $5 \mathrm{mM}$ potassium ferricyanide, $150 \mathrm{mM} \mathrm{NaCl}, 2 \mathrm{mM}$ $\mathrm{MgCl}_{2}, 1 \mathrm{mg} / \mathrm{ml} \mathrm{X-gal} \mathrm{in} \mathrm{dimethylformamide)} \mathrm{was} \mathrm{added.}$ The blue color became apparent after 12-16-h incubation
Fig. 1 Loss of TGF- $\beta$ cytostatic response in mesenchymal-like HCC cell lines. a Cell cycle analysis was performed using PI staining in the control and 3 days TGF- $\beta$-treated mesenchymal-like HCC cell lines. b TGF- $\beta$ treatment showed no effect on BrdU incorporation of mesenchymallike HCC cell lines. Cells were treated with $5 \mathrm{ng} / \mathrm{ml} \mathrm{TGF}-\beta$ for 3 days and subjected to immunofluorescence assay with anti-BrdU antibody. Positive cells in five random microscopic fields were manually counted with reference to DAPI positive nuclei. Huh7 cell line served as a positive control for TGF- $\beta$-induced cytostatic response $\mathbf{a}$ and $\mathbf{b}$. Control: no TGF- $\beta$ treatment

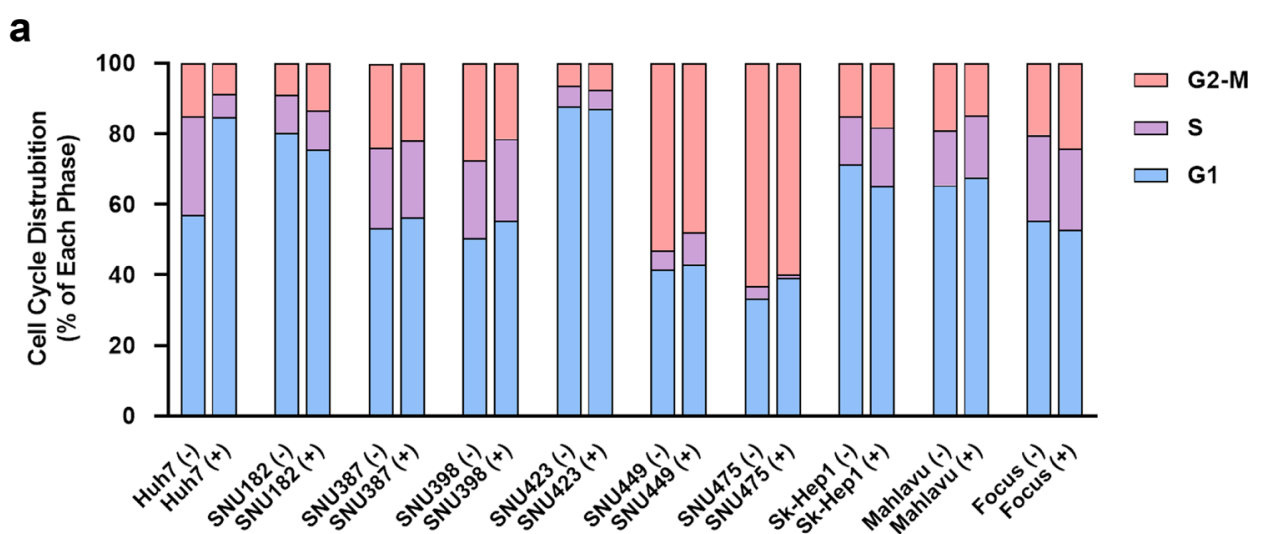

b

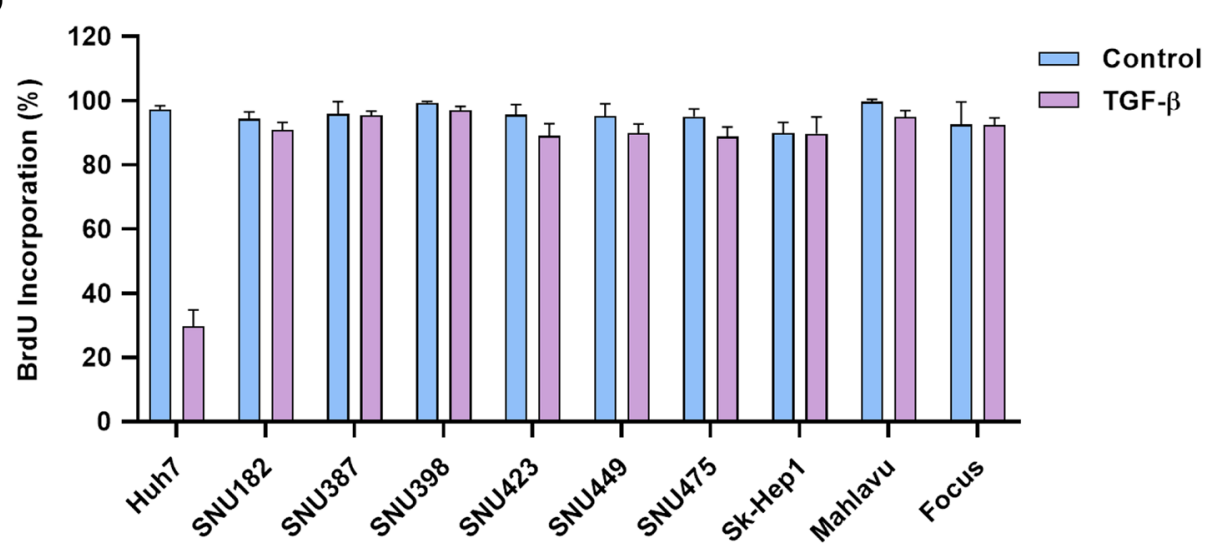


Fig. 2 Loss of TGF- $\beta$-mediated

senescence response in mesenchymallike HCC cell lines. Cells were treated with TGF- $\beta$ for 3 days and SA- $\beta-$ Gal activity (blue) was tested. Control: no TGF- $\beta$ treatment. Counterstain:

Nuclear Fast Red. Scale bar: 100 mm

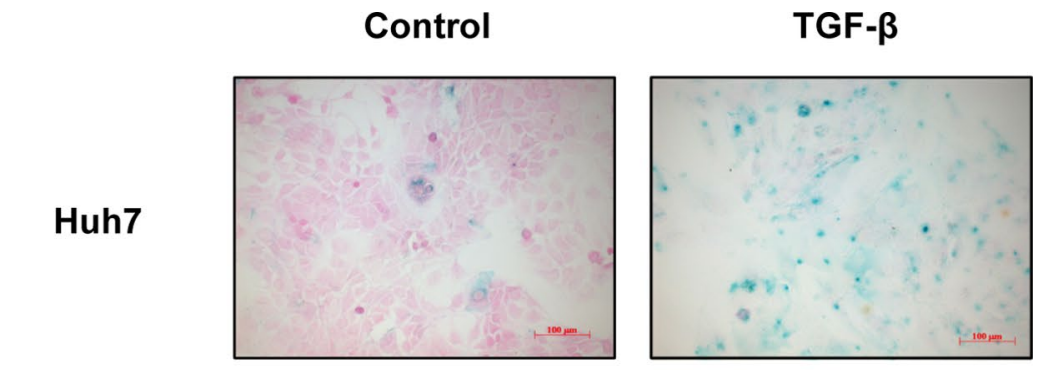

SNU423
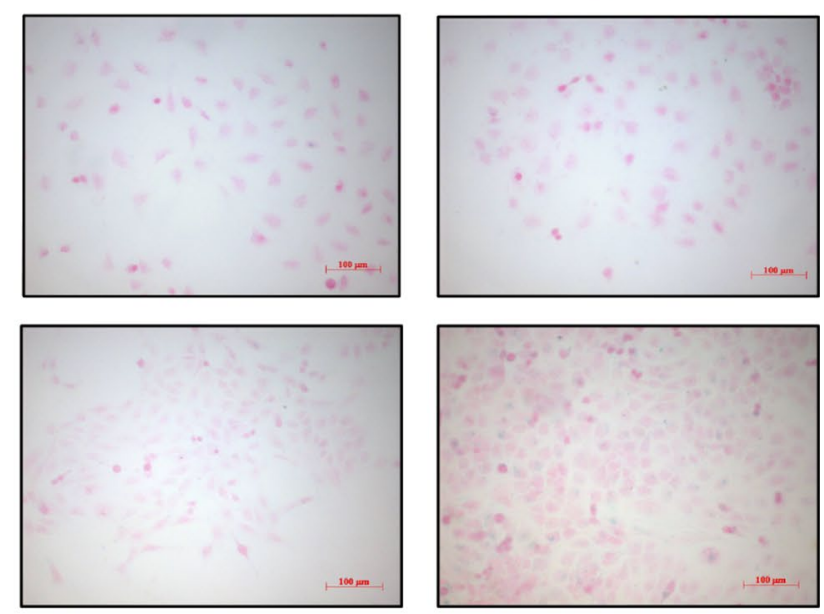

SNU449

SNU475

Sk-Hep1
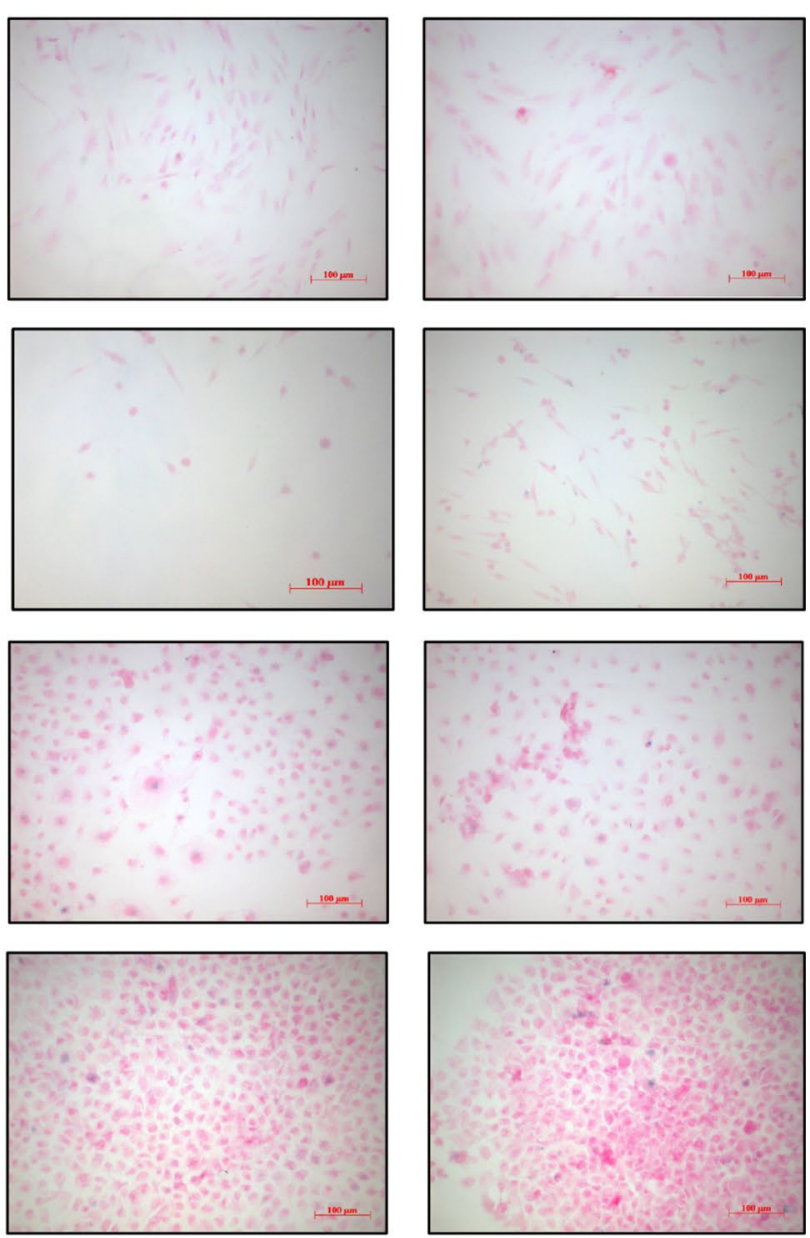

Focus 
in a $\mathrm{CO}_{2}$-free incubator at $37{ }^{\circ} \mathrm{C}$. After the blue color was fully developed, the cells were rinsed with PBS and counterstained with Nuclear Fast Red Staining Solution (Sigma).

\section{Cell Cycle Analysis}

The cells were collected by trypsinization, pelleted by centrifugation, resuspended in $1 \mathrm{ml}$ PBS, and fixed on ice with $2.5 \mathrm{ml} 100 \%$ ice-cold ethanol (the final concentration of ethanol is $70 \%$ ) for $15 \mathrm{~min}$. Fixed cells were collected by centrifugation $\left(1200 \mathrm{rpm}, 15 \mathrm{~min}, 4^{\circ} \mathrm{C}\right)$ and resuspended in $200 \mu \mathrm{l}$ PI solution $(50 \mu \mathrm{g} / \mathrm{ml}$ propidium iodide, $0.1 \mathrm{mg} / \mathrm{ml}$ RNase A, and $0.05 \%$ Triton X-100 in PBS), and incubated for $40 \mathrm{~min}$ at $37{ }^{\circ} \mathrm{C}$. Following centrifugation at $6000 \mathrm{rpm}$ for $5 \mathrm{~min}$ in a tabletop centrifuge, the stained cells were resuspended in $100 \mu \mathrm{l}$ PBS, transferred to polystyrene tubes equipped with a cell strainer cap, and analyzed on LSR Fortessa Flow Cytometer (BD Biosciences). The cell cycle profile was determined using the FlowJo software version 10.

\section{Luciferase Assays}

The pSBE4-Luc and p3TP-Lux, two reporter constructs with Firefly luciferase expression under the transcriptional regulation of canonical TGF- $\beta /$ Smad signaling, were individually cotransfected with the pRL-TK internal control vector (Promega) which provides constitutive expression of the Renilla luciferase under the control of herpes simplex virus thymidine kinase promoter. Transfection experiments were performed in triplicates in 24-well cell culture plates using Lipofectamine 2000 transfection reagent (Thermo Fisher Scientific) according to the manufacturer's instructions. Briefly, the cotransfection was carried out with $200 \mathrm{ng}$ reporter construct and $3 \mathrm{ng}$ pRL-TK vector. Six hour posttransfection, the cells were supplemented with a fresh culture medium containing $5 \mathrm{ng} / \mathrm{ml}$ TGF- $\beta$ and incubated for $24 \mathrm{~h}$ prior to the reporter assay. The Luciferase reporter assay was performed using the Dual Glo Luciferase Assay Kit (Promega), according to the manufacturer's instructions. The luminescence intensity of the Firefly luciferase was normalized to the Renilla luciferase.

\section{Results}

\section{Loss of TGF- $\beta$-Dependent Cytostatic Responses in Mesenchymal-Like HCC Cell Lines}

We previously demonstrated that activated TGF- $\beta$ signaling pathway in epithelial-like HCC cell lines can induce a stable cell cycle arrest in G1 phase, which is strongly correlated with a marked reduction in DNA synthesis (measured by BrdU labeling), indicating a strong cytostatic response in these cell lines [19]. To extend upon our existing knowledge, here we sought to conduct a systematic analysis of TGF- $\beta$-mediated cytostatic responses in a panel of nine mesenchymal-like HCC cell lines. Notably, the Sk-Hep1 cell line expresses mesenchymal markers, but is of endothelial origin derived from a liver adenocarcinoma. We employed the epithelial/hepatoblastlike Huh7 cell line, which we previously found to have a strong TGF- $\beta$-induced cytostatic response, as a positive control in this experimental setting [19]. To this end, we first performed a PI staining to investigate whether any of these cell lines would undergo TGF- $\beta$-induced cell cycle arrest. In striking contrast to the Huh7 cell line, which we noted a significant increase in G1-arrest (a rise from 57 to $85 \%$ ) accompanied by a reduction in $\mathrm{S}$ phase distribution (from 28 to nearly 7\%), the mesenchymal-like HCC cell lines did not have a notable difference in their cell cycle phases following 3 days of TGF- $\beta$ treatment (Fig. 1a). To further support these findings, we measured the proliferation rates of the entire cell line panel and compared them to Huh7 cells. To achieve this, we treated the cells with TGF- $\beta$ for 3 days and labeled them with BrdU for $24 \mathrm{~h}$. As anticipated, TGF- $\beta$ treatment resulted in a remarkable reduction in the proliferation index of Huh7 cells (nearly $70 \%$ ). Conversely, however, there was no discernible difference in BrdU incorporation of mesenchymal-like HCC cell lines (Fig. 1b). Taken together, we can safely conclude that TGF- $\beta$ treatment had no effect on the proliferation capacity of mesenchymal-like HCC cell lines, implying a selective and complete loss of TGF- $\beta$-dependent cytostatic responses in these cells.

\section{Loss of TGF- $\beta$-Mediated Senescence Response in Mesenchymal-Like HCC Cell Lines}

The cytostatic TGF- $\beta$ response in epithelial-like HCC cell lines is typically associated with massive senescence arrest, which can be readily identified via SA- $\beta$-Gal staining [19]. Based on the cell cycle profiles and BrdU labeling data, we hypothesized that the mesenchymal-like HCC cells would also fail to undergo cellular senescence upon TGF- $\beta$ treatment. To test this, we chose a subset of cell lines from the entire panel, treated them with TGF- $\beta$ for 3 days, and carried out the SA- $\beta-G a l$ assay. As depicted in Fig. 2, indeed, all tested cell lines were negative for SA- $\beta$-Gal assay while the positive control Huh7 cells showed an intense blue staining of the senescent cells. These results are consistent with cell cycle profiles and BrdU incorporation results, thus further suggesting that mesenchymal-like HCC cell lines have completely lost TGF- $\beta$-mediated cellular senescence responses. 


\section{Functional Characterization of TGF- $\beta$ Signaling from the Cell Membrane to the Nucleus in Mesenchymal-Like HCC Cell Lines}

The results presented in Figs. 1 and 2 raise the question of whether the TGF- $\beta$ pathway is somehow defective in these cell lines. The cytostatic TGF- $\beta$ resistance of mesenchymallike HCC cell lines can be caused by a variety of molecular mechanisms, including mutations in or loss of TGF- $\beta$ receptors, Smads, or associated mediators of the signaling cascade. On this account, we attempted to investigate the molecular and functional aspects of TGF- $\beta$ signaling from the cell membrane to the nucleus (Fig. 3a). To that purpose, first, we analyzed the curated TCGA (The Cancer Genome Atlas) dataset of 366 HCC patient samples through cBioPortal for Cancer Genomics [28]. We found that genetic
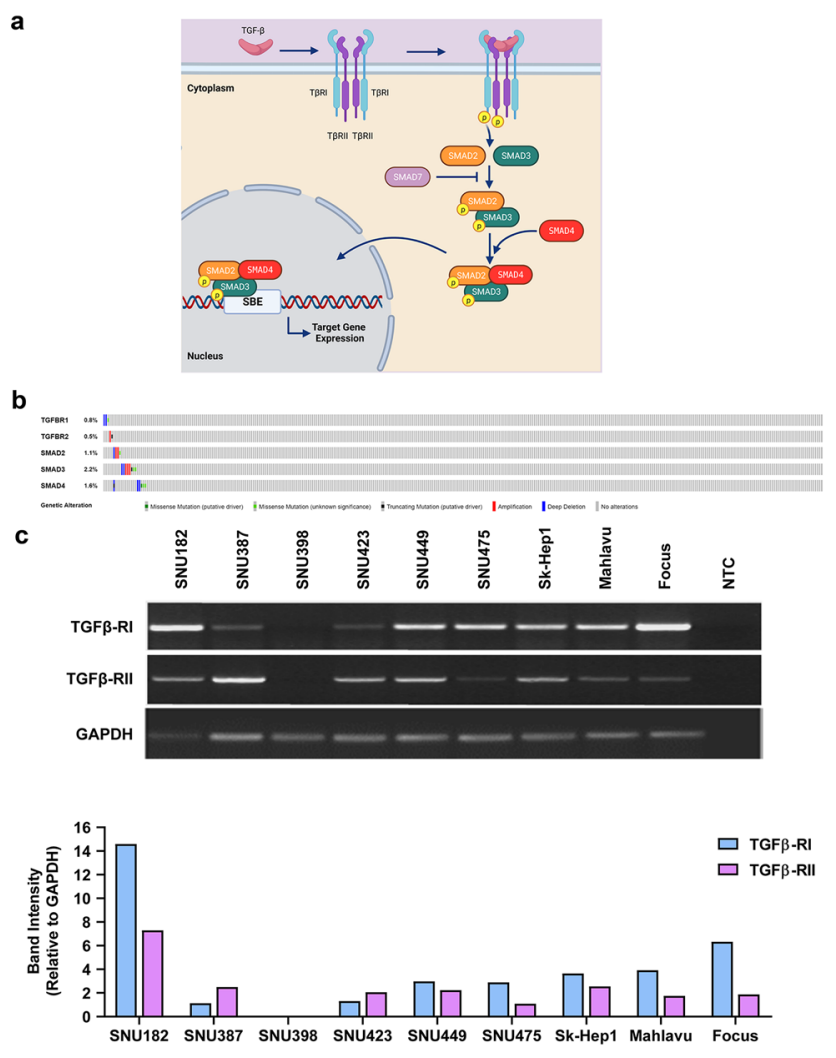

Fig. 3 Expression of canonical TGF- $\beta$ signaling cascade components in mesenchymal-like HCC cell lines. a Schematic of the canonical TGF- $\beta$ signaling pathway. TGF- $\beta$ signaling pathway initiates with the binding of the TGF- $\beta$ to TGF $\beta$-RII. TGF $\beta$-RII phosphorylates TGF $\beta$-RI and stimulates the kinase activity of TGF $\beta$-RI. Activated TGFß-RI phosphorylates the R-Smads ( $\mathrm{Smad} 2$ and Smad3) from their C-terminal serine residues. Next, phosphorylated R-Smads bind to Smad4, forming a heteromeric complex that eventually translocates into the nucleus. b Landscape of somatic mutations in the canonical alterations in the canonical TGF- $\beta$ pathway components of HCC patients were limited to $1.1 \%$ in SMAD2, $2.2 \%$ in SMAD3, $1.6 \%$ in SMAD4, $0.8 \%$ in TGF $\beta$-RI, and $0.5 \%$ in TGF $\beta$-RII, suggesting that genetic inactivations in HCC cell lines are also likely infrequent (Fig. 3b). Indeed, when we manually searched the Catalogue of Somatic Mutations in Cancer (COSMIC) (https://cancer.sanger.ac.uk/cosmic) and the Cancer Cell Line Encyclopedia (CCLE) (https:// depmap.org/portal/ccle/) databanks, as well as the Liver Cancer Cell Lines Database (https://lccl.zucmanlab.com/ hcc/cellLines) for potential genetic abnormalities in the same genes, we found no existing mutations in HCC cell lines (data not shown) $[8,29,30]$. Thereafter, using semiquantitative RT-PCR analysis of the relevant transcripts, we studied the mRNA expression of TGF $\beta$-RI and TGF $\beta$-RII in mesenchymal-like HCC cell lines and found that they were
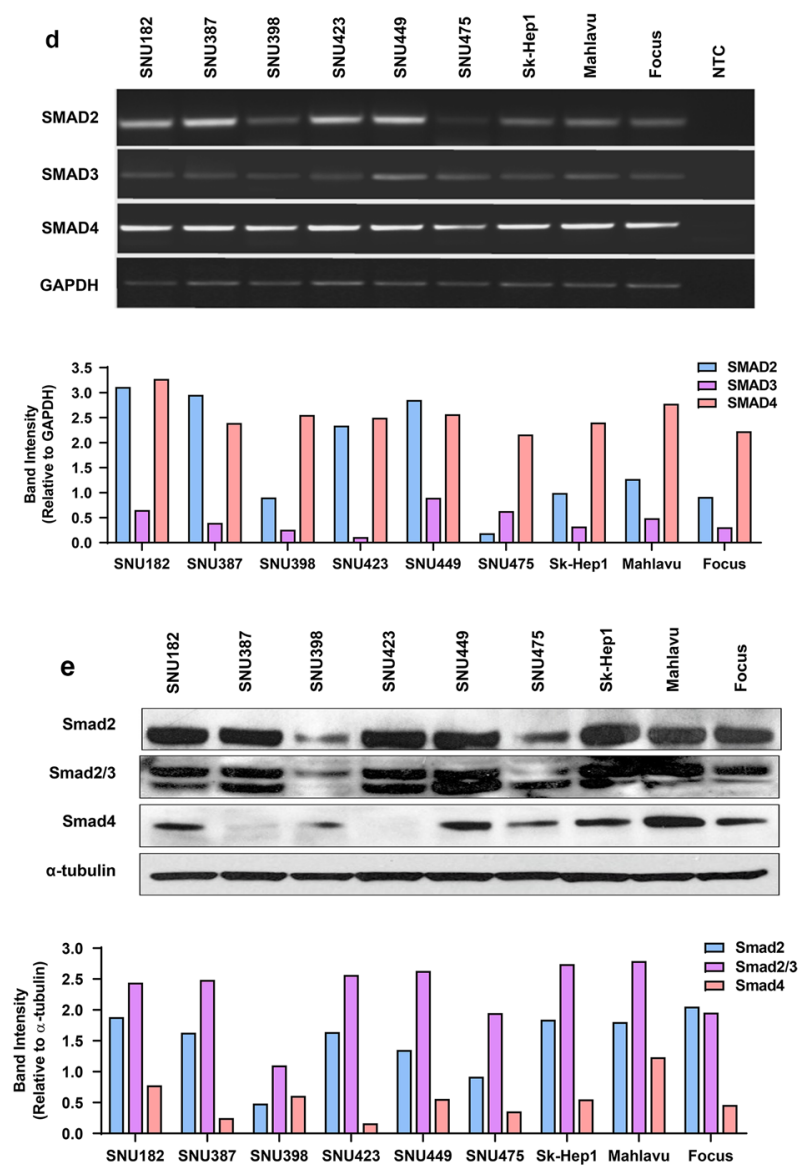

TGF- $\beta$ pathway genes in the TCGA dataset of 366 HCC samples. $\mathbf{c}$ RT-PCR analysis of TGF- $\beta$ receptors, TGF $\beta$-RI and TGFB-RII. d RT-PCR analysis of SMAD2, SMAD3, and SMAD4 genes. GAPDH was used as internal control in RT-PCR studies. e Expression profiles of Smad2, Smad3, and Smad4 proteins. Western blot analysis was performed using anti-Smad2, anti-Smad2/3, and anti-Smad4 antibodies. Anti- $\alpha$-tubulin was used as internal control. Relative band intensities were analyzed by the image processing program, ImageJ 

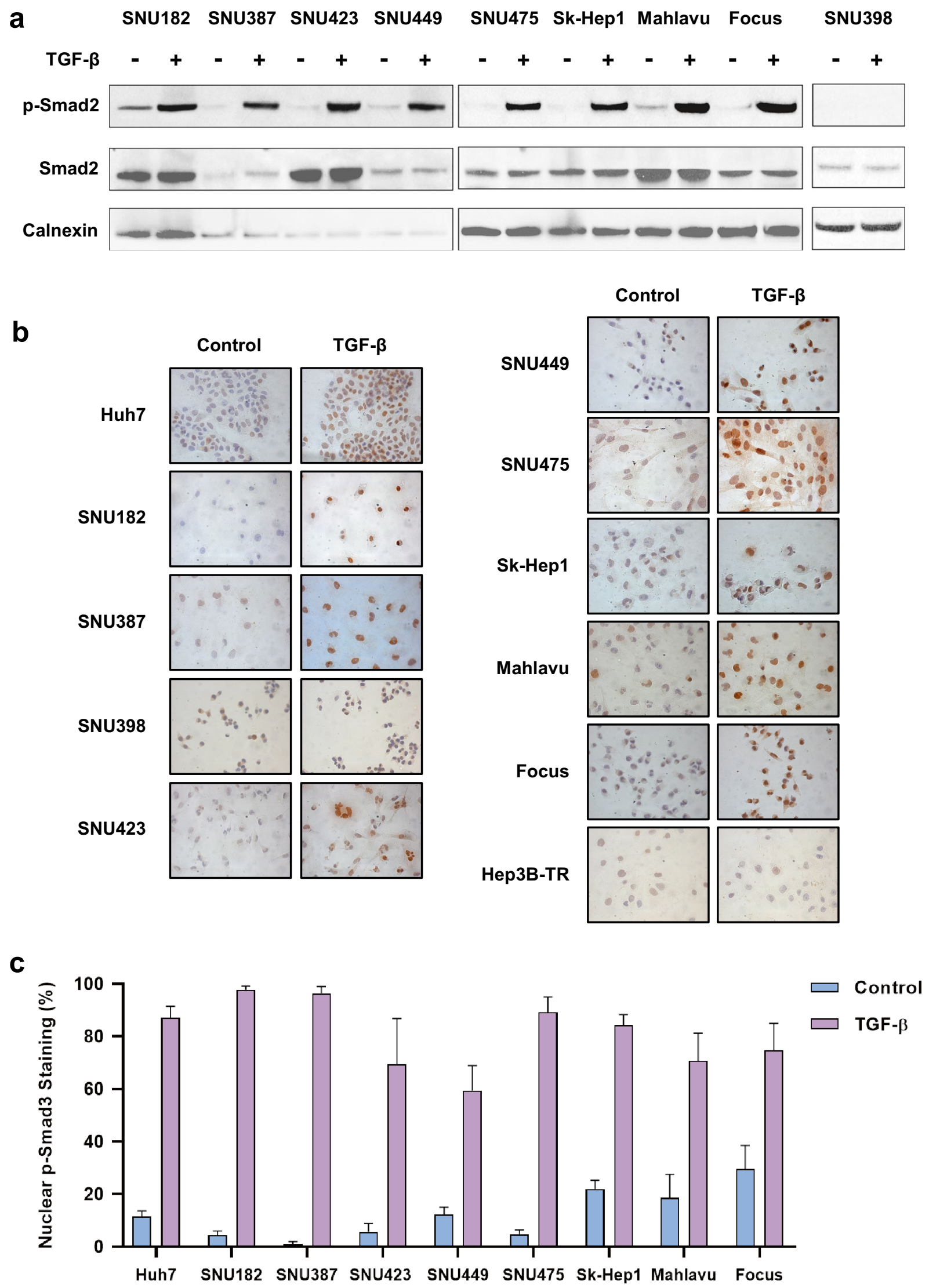
४Fig. 4 Mesenchymal-like HCC cell lines have an active canonical TGF- $\beta$ signaling cascade. a Increased phosphorylation of Smad2 (p-Smad2) levels following $30 \mathrm{~min}$ of TGF- $\beta$ stimulation. Calnexin was used as an internal control. b Subcellular localization of phosphorylated Smad3 (p-Smad3) upon TGF- $\beta$ treatment was studied by immunoperoxidase staining. To this end, cells were treated with TGF- $\beta$ for $30 \mathrm{~min}$ and stained with $\mathrm{p}-\mathrm{Smad} 3$ specific antibody. Hep3B-TR was used as a negative control. Hematoxylin was used as the nuclear counterstain (purplish blue color). c Nuclear p-Smad3 stainings (brown) were quantified by manual counting and normalized to the total number of nuclei

differentially expressed (Fig. 3c). Noteworthily, the expression was undetectable for both receptors in SNU398 cells, confirming a previous finding [31]. Second, we assessed the mRNA levels of SMAD2, SMAD3, and SMAD4 genes and found that the SMAD genes were expressed, albeit at varying levels, in the mesenchymal-like HCC cell lines (Fig. 3d). To corroborate these data, we performed western blot analysis to study the expression of Smad proteins. As a result, the expression patterns of Smad2 and Smad3 were found to be highly correlated with the mRNA levels. Similarly, Smad4 proteins were also comparable to the mRNA levels, with the exception of SNU387 and SNU423 cell lines, where the expression was barely detectable (Fig. 3e). Together, we conclude that the apparent lack of TGF- $\beta$-induced cytostatic responses in mesenchymal-like HCC cell lines cannot be explained by genetic inactivation or widespread loss of TGF- $\beta$ signaling components.

We then focused our efforts on the analysis of TGF $\beta$ RI-mediated activation of Smad signaling cascade, thus the C-terminal phosphorylation of cytoplasmic R-Smads. To investigate this, we treated the mesenchymal-like HCC cell lines with TGF- $\beta$ for $30 \mathrm{~min}$ and then examined the Cterminal phosphorylation of Smad2 (p-Smad2, Ser465/467) by western blotting. When compared to untreated control cell lysates, total $\mathrm{p}$-Smad2 levels were significantly augmented in TGF- $\beta$-treated samples (Fig. 4a). Importantly, however, SNU398 cells were completely devoid of TGF- $\beta$ dependent Smad2 phosphorylation, which can be explained by diminished TGF- $\beta$ receptor expression rendering this cell line deficient in canonical TGF- $\beta$ signaling. These data strongly substantiate that all mesenchymal-like HCC cell lines, with the exception of SNU398, are competent for TGF- $\beta$-mediated R-Smad phosphorylation.

Arguably, the loss of TGF- $\beta$-induced cytostasis in cancer cells can be associated with impaired nuclear shuttling of R-Smads. To study the modulation of signal transduction of receptor-activated Smad molecules from the cell membrane to the nucleus, we sought to investigate the subcellular distribution of phosphorylated Smad3 (p-Smad3, Ser423/425) by an immunoperoxidase staining assay after TGF- $\beta$ treatment. In this setting, Huh7 and Hep3B-TR, a TGF- $\beta$-resistant cell line with a complete loss of TGF $\beta$-RII expression, were selected as positive and negative control cell lines, respectively (Fig. 4b). Nuclear p-Smad3 stainings (brown color) were quantified by manual counting (Fig. 4c). As expected, the nuclear p-Smad3 signal was undetectable in Hep3B-TR and SNU398 cell lines. Hence, we excluded them from the quantification analysis. As a result, we found that all cell lines, with an obvious exception of Hep3B-TR and SNU398, exhibited significantly enhanced and robust nuclear staining upon TGF- $\beta$ stimulation. Together, we conclude that most of mesenchymal-like HCC cell lines have an intact and sufficient canonical TGF- $\beta$ signaling cascade.

\section{Transcriptional Response of Mesenchymal-Like HCC Cell Lines to TGF- $\beta$ Stimulation}

When phosphorylated, R-Smads form transcriptional complexes with the common partner Smad4, accumulate in the nucleus, and regulate the expression of many target genes, some of which are critical for cytostatic TGF- $\beta$ responses. To elucidate the transcriptional TGF- $\beta$ responsiveness of mesenchymal-like HCC cell lines, we exploited two well-

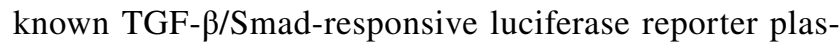
mids, pSBE4-Luc and p3TP-Lux.

The pSBE4-Luc reporter construct constitutes four tandem copies of 8-bp palindromic consensus Smad binding elements (SBE, 5'-GTCTAGAC-3') positioned upstream of an SV40 minimal promoter and uniquely measures TGF$\beta$-dependent Smad complex-driven transcriptional activity. When transiently transfected into cells and stimulated with TGF- $\beta$ for $24 \mathrm{~h}$, the pSBE4-Luc reporter activity increased by 2.5 - to sixfold (Fig. 5a). Specifically, SNU449 had the strongest response of all cell lines ( sixfold), while Focus was the weakest ( 2.5 fold). Predictably, SNU398 cells were completely unresponsive to TGF- $\beta$ treatment. The p3TP-Lux reporter construct, on the other hand, entails an artificial promoter consisting of three consecutive repeats of the tetradecanoyl phorbol acetate (TPA)-response elements (TREs, 5'-TGA G/C TCA-3') and a small region of the plasminogen activator inhibitor-1 (PAI-1) promoter, a well-known TGF- $\beta$-target gene. When compared to pSBE4-Luc reporter results, transient transfection of the p3TP-Lux reporter and treatment with TGF- $\beta$ for $24 \mathrm{~h}$ resulted in slightly less and variable but substantially higher transcriptional activity ( up to fivefold) in the mesenchymal-like cell line panel, except for the SNU398 and SNU182 which were not affected by TGF- $\beta$ treatment (Fig. 5b). To strengthen these findings, we conducted an RT-PCR analysis for PAI-1 (SERPINE1 gene) mRNA expression in SNU387, SNU449, and Mahlavu cell lines which exhibited the highest luciferase activity for p3TP-Lux reporter construct. Consequently, we observed a modest increase in PAI-1 transcript levels after 3 days of TGF- $\beta$ treatment, partly confirming the luciferase reporter data (Fig. 5c). In summary, virtually similar findings were 
a

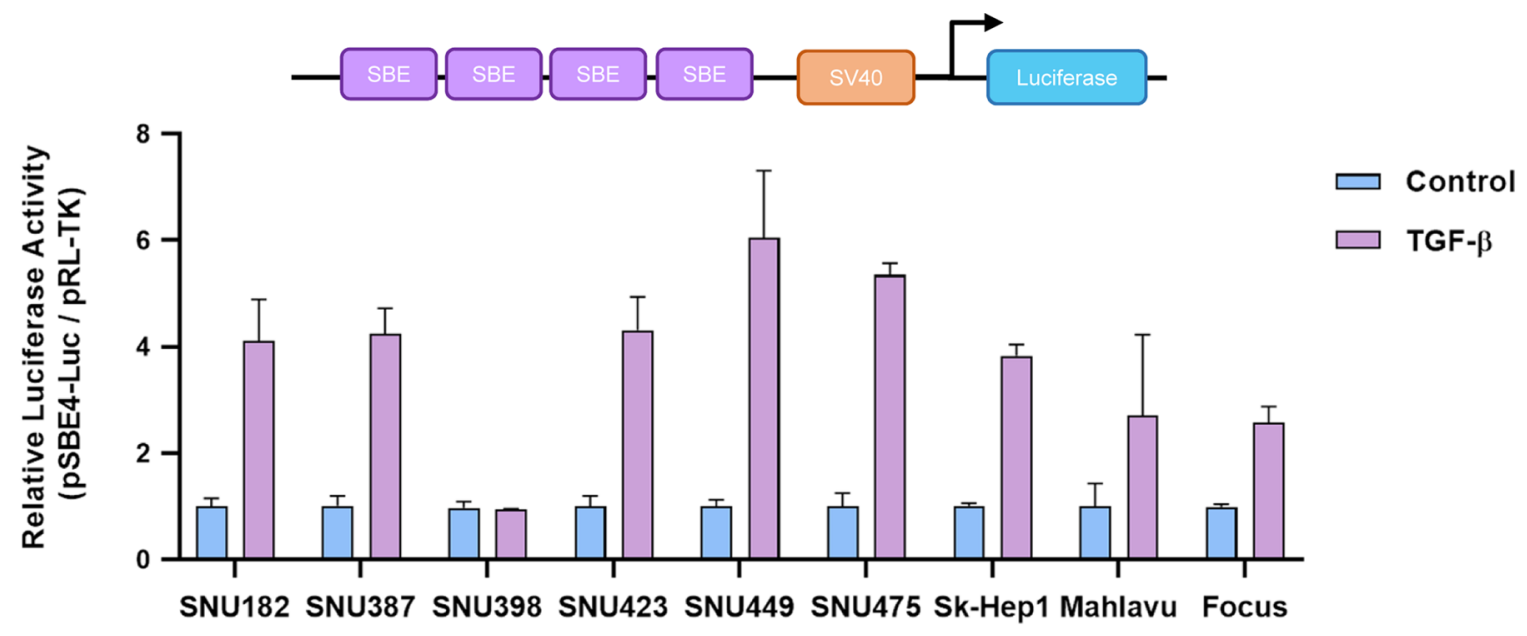

b

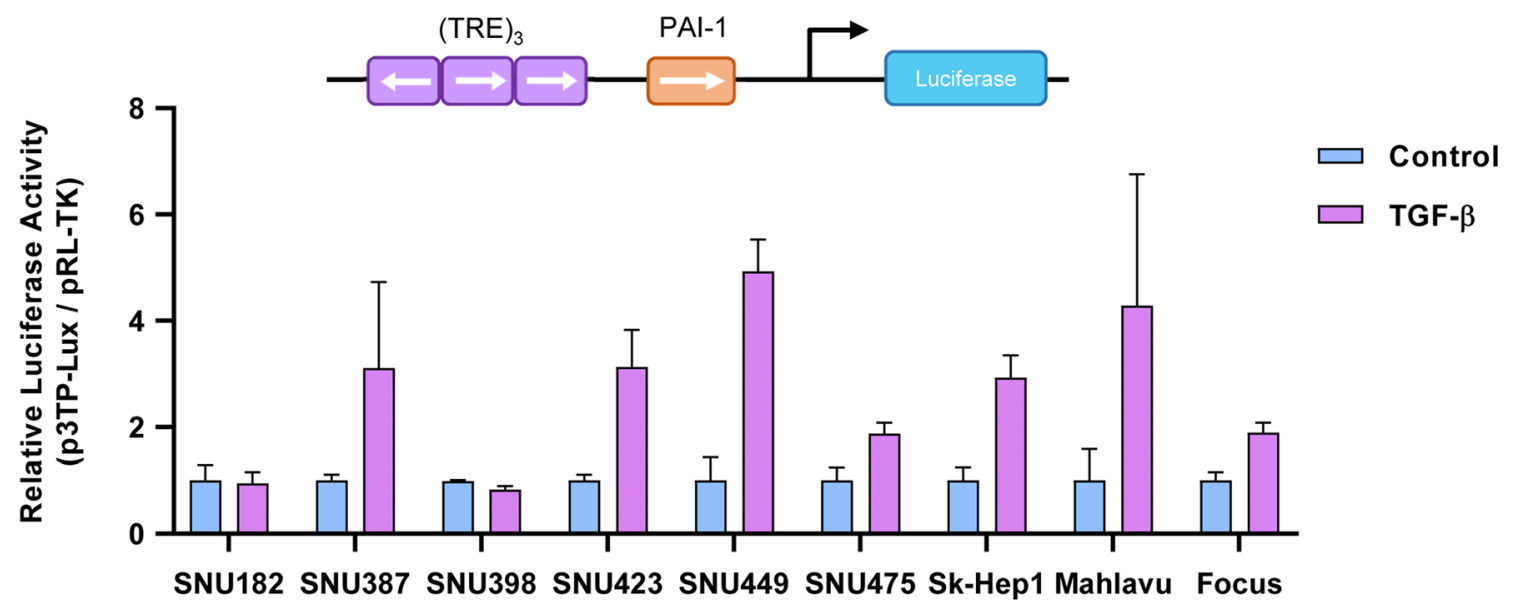

C
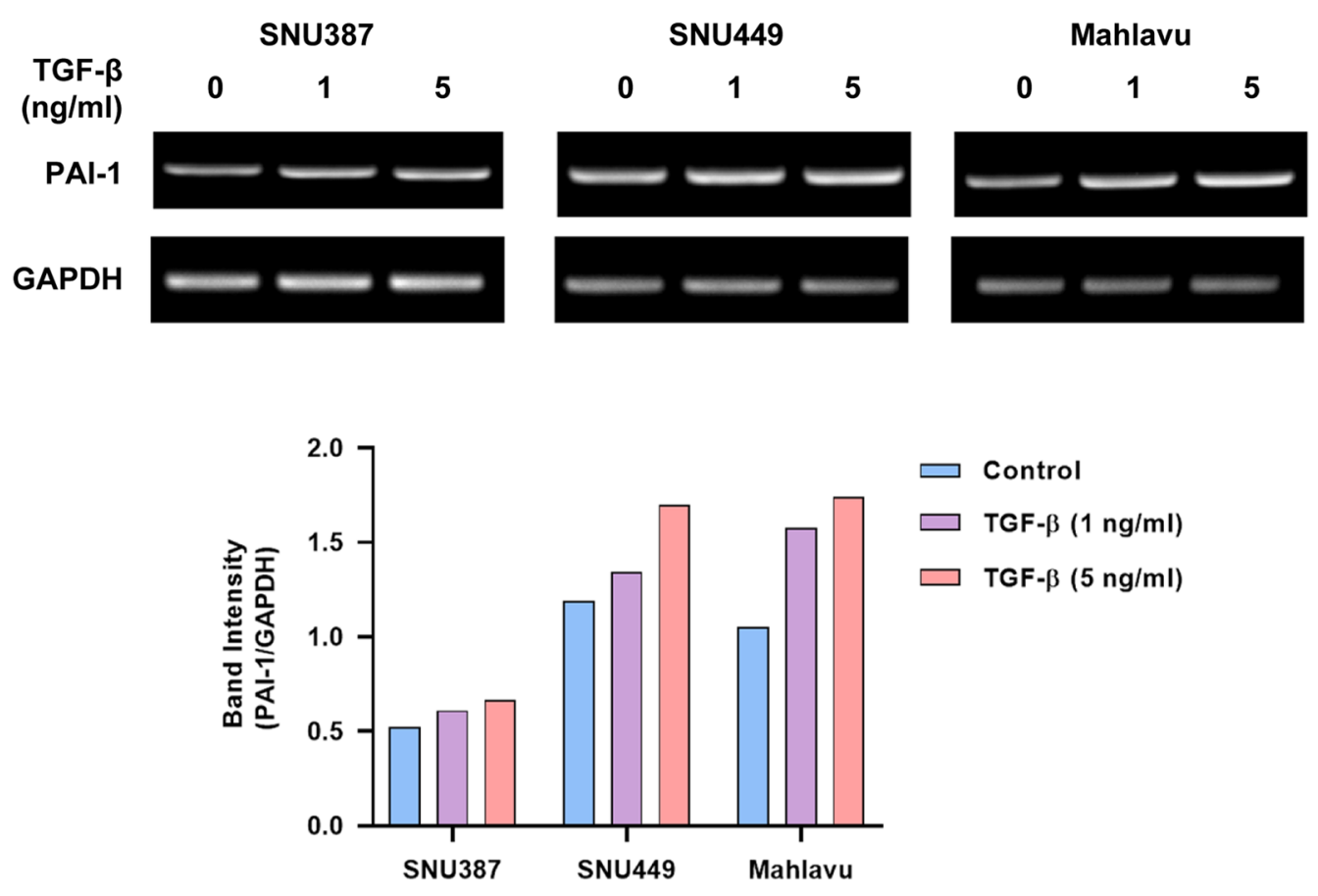
4Fig. 5 Transcriptional response of mesenchymal-like HCC cell lines to TGF- $\beta$ stimulation. a Schematic representation of the pSBE4Luc reporter and the responsiveness of mesenchymal-like HCC cell lines by pSBE4-Luc activation. The pSBE4-Luc reporter construct consists of four tandem copies of 8-bp palindromic consensus Smad binding elements (SBE) and an SV40 minimal promoter. b Schematic representation of the $\mathrm{p} 3 \mathrm{TP}-\mathrm{Lux}$ reporter and the responsiveness of mesenchymal-like HCC cell lines by p3TP-lux activation. p3TPLux reporter consists of three (TPA)-response elements (TREs) and PAI-1 promoters. All cell lines were cotransfected with pSBE4-Luc and pRL-TK vectors a or p3TP-Lux and pRL-TK vectors b. Luciferase activity of pSBE4-Luc and p3TP-Lux Firefly luciferase reporter constructs was normalized to the pRL-TK Renilla luciferase activity. All experiments were performed in triplicate. c RT-PCR analysis for PAI-1 mRNA expression in SNU387, SNU449, and Mahlavu cell lines after 3 days of TGF- $\beta$ treatment. Relative PAI-1/GAPDH intensity was analyzed by the image processing program, ImageJ. Relative intensity of untreated cells was normalized 100 . The graph was drawn according to normalized values

observed for both luciferase reporters and the data clearly demonstrate that 7 out of 9 mesenchymal HCC cell lines are transcriptionally responsive to TGF- $\beta$ treatment revealing that the loss of cytostatic regulation by TGF- $\beta$ is not related to Smad-dependent signaling cascade. Of particular importance, the lack of detectable Smad4 protein expression in SNU387 and SNU423 cell lines did not affect TGF- $\beta$ induced reporter activity.

\section{Expression of Cytostatic Genes in Mesenchymal-Like HCC Cell Lines}

As we previously demonstrated, the cytostatic TGF- $\beta$ response of epithelial-like HCC cells was associated with increased expression of several downstream effector genes including cyclin-dependent kinase (CDK) inhibitors, specifically $\mathrm{p} 21^{\text {Cip } 1}$ (encoded by the $C D K N 1 A$ gene) and $\mathrm{p} 15^{\text {Ink } 4 \mathrm{~b}}$ (encoded by the $C D K N 2 B$ gene) tumor suppressor genes. These changes were accompanied by a reciprocal decrease in $\mathrm{pRb}$ phosphorylation (p-pRb) [19]. In order to specify whether the resistance to TGF- $\beta$-induced growth arrest could be explained by the regulation of these cytostatic effector genes, we studied their expression in mesenchymal-like HCC cells. To this end, we treated a subset of the entire cell line panel with different doses of TGF- $\beta$ for 3 days and then evaluated the levels of mRNA and protein expression by means of RT-PCR assay and western blot analysis, respectively. Strikingly, TGF- $\beta$ treatment had no effect on the expression of the $\mathrm{p} 21^{\mathrm{Cip} 1}$ and $\mathrm{p} 15^{\mathrm{Ink} 4 \mathrm{~b}}$ tumor suppressor proteins. Furthermore, none of the cell lines, with the exception of SNU387, showed a change in the pRb phosphorylation (Fig. 6a). Notably, decreased levels of p-pRb in SNU387 cells do not correlate with the loss of TGF- $\beta$ induced cytostatic response in this cell line, making this finding important yet contextually insignificant. Another key finding in the western blot results was the absence of p15 ${ }^{\text {Ink4b }}$ protein expression in SNU387, SNU449, and SkHep1 cell lines. Based on this observation, we studied the expression of $C D K N 2 B$ gene at the transcript level in the entire cell line panel and verified that these three cell lines had no mRNA expression (Fig. 6b). Finally, using specific primers, we performed genomic PCR and amplified the INK4 locus in cell lines lacking $C D K N 2 B$ expression and showed that SNU387, SNU449, and Sk-Hep1 cell lines carry a deletion at the $C D K N 2 B$ gene (Fig. 6c), confirming the findings of a previous study [32]. To extend this analysis, we studied the protein expression of p14 ${ }^{\text {Arf }}$ (encoded by the $A R F$ gene) and $16^{\text {Ink4a }}$ (encoded by the $C D K N 2 A$ gene), two other tumor suppressor genes encoded by the INK4 locus, by western blotting and found that the same cell lines did not express these proteins (Fig. 6d), which is in agreement with other studies highlighting the homozygous loss of this locus in HCC tumors [33, 34]. Furthermore, with the exception of SNU182, the expression of $\mathrm{p} 16^{\text {Ink4a }}$ protein was not detected in the remaining cell lines with an intact INK4 locus, a critical observation that is consistent with the hypermethylation of the $C D K N 2 A$ promoter region $[32,35]$. Overall, these results indicate that TGF- $\beta$ treatment fails to upregulate the expression of cytostatic effector genes in mesenchymal-like HCC cell lines, and more importantly, the INK4 locus, specifically $C D K N 2 B$ gene, is lost in several cell lines.

\section{Discussion}

Hepatocellular carcinoma is currently the fourth leading cause of cancer-related death worldwide, with a projection to become the third leading cause by the year 2030 [2]. Despite increasing knowledge on the etiological factors and the molecular mechanisms driving HCC, therapeutic options for this lethal malignancy remain limited [36, 37]. The canonical TGF- $\beta$ pathway is strongly implicated in HCC development, playing dual functions involving both tumor suppression at early stages and oncogenesis at advanced stages [38]. Hepatocellular carcinoma patients with prooncogenic TGF- $\beta$ signature tumors are associated with a significantly shorter mean survival time [20]. Furthermore, HCC tumors with late-stage TGF- $\beta$ signatures are characterized by overexpression of positive cell cycle regulators, and angiogenesis genes, as well as a more aggressive phenotype associated with poor clinical outcomes, rendering TGF- $\beta$ / Smad signaling cascade a promising therapeutic target in HCC [39].

Established human HCC cell lines replicate to a large extent stage-specific characteristics of tumors, particularly the phenotypic classification based on epithelial and mesenchymal marker gene expressions. Of particular relevance to TGF- $\beta$, a prior study found that when the epithelial-like and mesenchymal-like HCC cell lines were challenged with TGF- $\beta$ for different time intervals, they exhibited early and 
Fig. 6 Lack of cytostatic effector gene expressions in mesenchymal-like HCC cell lines. a Cells were treated with different doses of TGF- $\beta$ and assayed for protein expression by western blotting. All incubations were essentially performed at room temperature. Anti$\alpha$-tubulin served as internal control. b RT-PCR analysis for $\mathrm{p} 15^{\text {Ink4b }}(C D K N 2 B)$ and $\mathrm{p} 16^{\text {Ink4a }}$ $(C D K N 2 A)$ genes in all HCC cell lines. GAPDH served as internal control. c GenomicPCR analysis for selected regions on $C D K N 2 B$ gene in all mesenchymal-like HCC cell lines. d Western blot analysis for $\mathrm{p} 14^{\text {Arf }}, \mathrm{p} 15^{\text {Ink4b }}$, and $\mathrm{p} 16^{\text {Ink4a }}$ genes in mesenchymal-like HCC cell lines. Anti- $\alpha$-tubulin served as internal control. Relative band intensities were analyzed by the image processing program, Image J a



b

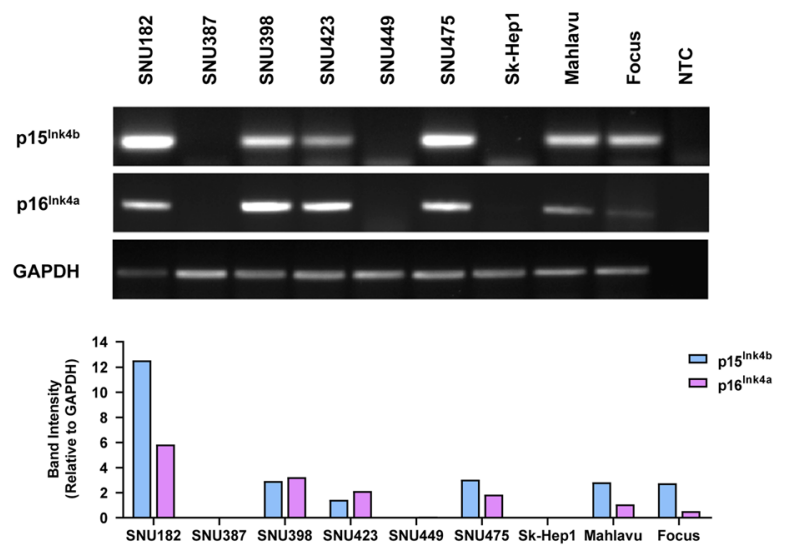

C

d
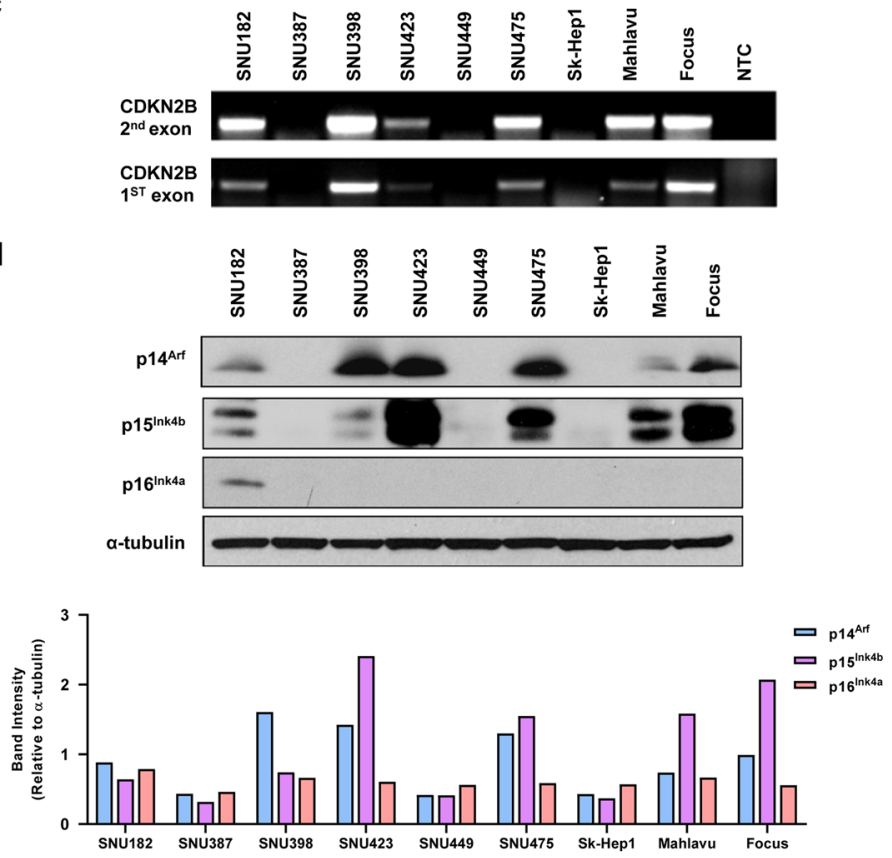
Table 1 Characteristics of cell lines used in this study

\begin{tabular}{llllllll}
\hline Cell line & Histology & Gender & Age & Ethnicity & HBV & HCV & References \\
\hline Huh7 & HCC & Male & 57 & Japan & No & No & {$[21]$} \\
SNU182 & HCC & Male & 24 & Korea & Yes & No & {$[22]$} \\
SNU387 & HCC & Female & 41 & Korea & Yes & No & {$[22]$} \\
SNU398 & HCC & Male & 42 & Korea & Yes & No & {$[22]$} \\
SNU423 & HCC & Male & 40 & Korea & Yes & No & {$[22]$} \\
SNU449 & HCC & Male & 52 & Korea & Yes & No & {$[22]$} \\
SNU475 & HCC & Male & 43 & Korea & Yes & No & {$[22]$} \\
Sk-Hep1 & LAC & Male & 52 & Caucasian & No & NA & {$[23,24]$} \\
Mahlavu & HCC & Female & NA & African & Yes & NA & {$[25]$} \\
Focus & HCC & Male & 63 & USA & Yes & NA & {$[26]$} \\
Hep3B-TR & HCC & Male & 8 & African/American & Yes & No & {$[27]$} \\
\hline
\end{tabular}

$H C C$, hepatocellular carcinoma; $L A C$, liver adenocarcinoma (endothelial origin); $N A$, not available late TGF- $\beta$ gene signatures, respectively. Interestingly, early TGF- $\beta$ signature was an indication of TGF- $\beta$-induced cytostasis and apoptosis [20]. Consistent with this, several independent studies confirmed that TGF- $\beta$ can inhibit cell viability and induce apoptosis in epithelial-like HCC cell lines [40, 41]. More recently, the publication from our group has demonstrated for the first time that TGF- $\beta$ provokes a robust cytostatic senescence response in epithelial-like HCC cells and functions as a barrier against tumor growth in vivo [19]. In contrast, late TGF- $\beta$ signature in mesenchymal-like HCC cell lines was characterized by TGF- $\beta$-induced invasiveness and EMT, further suggesting that these cell lines were competent for studying tumor promoting activities of TGF- $\beta$ pathway [20]. A relevant and important question from this point of view is whether mesenchymal-like HCC cell lines have selectively and completely lost TGF- $\beta$-induced cytostatic responses while maintaining others. Thus, a comprehensive and systematic study on the mesenchymal-like HCC cell lines would significantly contribute to the understanding of phenotype-specific cytostatic activities of TGF$\beta$. With this motivation, we investigated and demonstrated that TGF- $\beta$-induced cytostatic responses, specifically cell cycle arrest, proliferative capacity (as determined by BrdU incorporation), and cellular senescence, have been lost in mesenchymal-like HCC cell lines. Consistent with our findings, Kim et al. have recently reported the absence of cytostatic TGF- $\beta$ response in SNU387, SNU475, and SK-Hep1 cell lines. Unlike what is reported in our study, however, they found the SNU449 cell line to exhibit a mild cytostatic response when compared to epithelial-like HCC cell lines, presumably manifested by a distinct experimental setting which relied on 6 days of TGF- $\beta$ treatment [42].
Table 2 Primary and secondary antibodies

\begin{tabular}{|c|c|c|c|}
\hline Antibodies & Company and catalog number & $\begin{array}{l}\text { Western blot } \\
\text { working dilution }\end{array}$ & $\begin{array}{l}\text { Immunostaining } \\
\text { working dilution }\end{array}$ \\
\hline Calnexin & Sigma, C4731 & $1: 10000(\mathrm{RT})$ & - \\
\hline $\begin{array}{l}\text { p-Smad3 } \\
\text { (Ser423/425) }\end{array}$ & Cell Signaling, 9514 & $1: 1000(\mathrm{ON})$ & $1: 150$ (IP) \\
\hline $\begin{array}{l}\text { p-Smad2 } \\
\text { (Ser465/467) }\end{array}$ & Cell Signaling, 3101 & $1: 1000(\mathrm{ON})$ & - \\
\hline Smad4 & Santa Cruz, sc7966 & $1: 1000(\mathrm{ON})$ & - \\
\hline $\operatorname{Smad} 2 / 3$ & BD Biosciences, 610,843 & $1: 1000(\mathrm{ON})$ & - \\
\hline $\mathrm{p} 15^{\text {Ink4b }}$ & Santa Cruz, sc612 & $1: 400(\mathrm{RT})$ & - \\
\hline $\mathrm{p} 21^{\mathrm{Cip} 1}$ & Calbiochem, OP64 & 1:100 (RT) & - \\
\hline p53 & BD Biosciences, 554,293 & 1:500 (RT) & - \\
\hline$\alpha$-tubulin & Calbiochem, CP06 & $1: 10,000(\mathrm{RT})$ & - \\
\hline p-Rb (Ser807/811) & Cell Signaling, 9308 & $1: 1000(\mathrm{ON})$ & - \\
\hline $\mathrm{p} 16^{\text {Ink4a }}$ & Calbiochem, NA29 & $1: 250(\mathrm{RT})$ & - \\
\hline BrdU & Cell Signaling, 5292 & - & $1: 1000$ (IF) \\
\hline Anti-mouse Alexa Fluor 488 & Abcam, 150,105 & - & $1: 1000(\mathrm{IF})$ \\
\hline
\end{tabular}

$I F$, immunofluorescence; $I P$, immunoperoxidase; $R T$, room temperature; $O N$, overnight at $+4{ }^{\circ} \mathrm{C}$ 
Table 3 Oligonucleotides

\begin{tabular}{|c|c|c|}
\hline Primer ID & Sequence $\left(5^{\prime}-3^{\prime}\right)$ & $\begin{array}{l}\text { Product } \\
\text { size (bp) }\end{array}$ \\
\hline GAPDH-F & GGCTGAGAACGGGAAGCTTGTCAT & 169 \\
\hline GAPDH-R & CAGCCTTCTCCATGGTGGTGAAGA & \\
\hline Smad2-F & CGAAATGCCACGGTAGAAAT & 130 \\
\hline Smad2-R & GATTACAATTGGGGCTCTGC & \\
\hline Smad3-F & CAGAGTGCCTCAGTGACAGC & 134 \\
\hline Smad3-R & AGCGAACTCCTGGTTGTTGA & \\
\hline Smad4-F & TTTGGGTCAGGTGCCTTAGT & 142 \\
\hline Smad4-R & TGACACTGACGCAAATCAAAG & \\
\hline TGF $\beta-R I-F$ & TTGTGGCACGGTGAGAGTGT & 865 \\
\hline TGF $\beta-R I-R$ & TGCTCCTGGGCTATTGAATCA & \\
\hline TGF $\beta$-RII-F & GTTAACCGGCAGCAGAAGCT & 401 \\
\hline TGF $\beta$-RII-R & ATCAGCCAGTATTGTTTCCC & \\
\hline PAI-1-F & CACCCTCAGCATGTTCATTG & 188 \\
\hline PAI-1-R & CCAGGTTCTCTAGGGGCTTC & \\
\hline $\mathrm{p} 15^{\text {Ink4b }}-\mathrm{F}$ & ATGCGCGAGGAGAACAAG & 138 \\
\hline $\mathrm{p} 15^{\text {Ink4b }}-\mathrm{R}$ & GAAACGGTTGACTCCGTTG & \\
\hline $\mathrm{p} 16^{\text {Ink4a }}-\mathrm{F}$ & GGGTCCCAGTCTGCAGTTA & 131 \\
\hline $\mathrm{p} 16^{\text {Ink4a }}-\mathrm{R}$ & GGAGGGTCACCAAGAACCT & \\
\hline
\end{tabular}

As surveyed in the literature and the Liver Cancer Cell Lines database, mesenchymal-like HCC cell lines do not have detectable genetic aberrations in the canonical TGF- $\beta$ pathway, suggesting that non-genetic mechanisms can potentially drive this phenomenon [ $8,43,44]$. These findings were further corroborated in the TCGA dataset of HCC patients, which showed that inactivating mutations in the core TGF- $\beta$ signaling components were relatively rare in HCC. In addition to these, our results revealed that the entire cell line panel retained the mRNA expression of canonical TGF- $\beta /$ Smad signaling molecules, except for the SNU398. These observations were in line with the report that linked deregulated TGF- $\beta$-RII and beta-spectrin ELF expression, a Smad 3 and Smad4 adaptor, to acquired resistance of TGF- $\beta$-mediated growth arrest in SNU398 cell line [31]. Surprisingly, despite the fact that SMAD4 gene was expressed at the mRNA level in all cell lines, protein expression was not observed in SNU387 and SNU423 cell lines, a finding we deemed biologically insignificant as detailed below.

As described earlier, phosphorylated Smad2 and Smad3 form a heteromeric complex with Smad4 in the canonical TGF- $\beta$ signaling cascade. This complex translocates into the nucleus, binds to DNA, and participates in the transcriptional activation or repression of various target genes. On this basis, deregulated translocation of this complex was proposed as a TGF- $\beta$ resistance mechanism in various cancer models with intact TGF- $\beta$ receptors [45-47]. In order to test this, we analyzed all cell lines for nuclear Smad3 accumulation. The immunoperoxidase staining assay for $\mathrm{p}$-Smad 3 pointed out that the cascade of signaling events from the cell membrane to the nucleus was functional in the vast majority of mesenchymal-like HCC cell lines. Furthermore, using two well-known TGF- $\beta /$ Smad-responsive luciferase reporter plasmids, we demonstrated that the mesenchymallike HCC cell lines had an active transcriptional response. Despite the lack of Smad4 protein expression, SNU387 and SNU423 cell lines had increased reporter activity for the p3TP-Lux construct. Intriguingly, the SNU182 cell line with Smad4 protein expression did not have the reporter activity. We speculate this finding may reflect the context-specific nature of Smad-dependent transcriptional regulation by cofactors that can bind to the 3 TP promoter and possess repressor activities [48, 49]. Such that, the overexpression of $Z E B 2$ gene was associated with TGF- $\beta$ pathway functions in EMT and suppression of target gene activation [50-52]. Recently, increased expression of ZEB2 has been described for mesenchymal-like HCC cell lines, featuring a potential cofactor with repressive functions [53]. Having demonstrated that the signaling cascade for TGF- $\beta$ pathway was effective at the transcriptional level in mesenchymallike HCC cell lines, we wondered why these cells did not respond to TGF- $\beta$ treatment with a growth arrest. Therefore, we studied the expression of tumor suppressor genes $\left(\mathrm{p} 21^{\text {Cip } 1}\right.$ and $\left.\mathrm{p} 15^{\text {Ink } 4 \mathrm{~b}}\right)$ that were previously associated with a strong cytostatic TGF- $\beta$ response in epithelial-like HCC cell lines. Interestingly enough, the expression levels of these markers were not altered upon TGF- $\beta$ treatment. More importantly, we found that three cell lines, namely SNU387, SNU449, and Sk-Hep1, were $\mathrm{p} 15^{\text {Ink4b }}$-deficient, a key finding that we and others attributed to a deletion at the INK4 locus [32].

One fundamental limitation of the current study is that we do not present a definitive mechanism for the lack of cytostatic TGF- $\beta$ responses in mesenchymal-like HCC cell lines. Given the complexity of the genetic nature of HCC, and the cellular mechanisms governing TGF$\beta$-regulated molecular processes, we strongly argue that multiple mechanisms might converge in this phenomenon, making it potentially challenging to identify a shared molecular mechanism, if it exists, with the current methodology. We contend, however, that a plausible explanation for this phenomenon would be a deregulation in the transcriptional activation or genetic loss of cytostatic effector genes that control TGF- $\beta$-induced cytostatic responses. Further studies may certainly shed light on the mechanisms that drive cell line-specific insensitivity to TGF- $\beta$-induced cytostasis. 


\section{Conclusions}

In conclusion, this study shows that mesenchymal-like HCC cells have selectively lost the cytostatic TGF- $\beta$ responses without compromising the intactness of the canonical TGF- $\beta$ signaling cascade from the cell membrane to the nucleus, highlighting the potential utility of these cell lines to investigate in detail the molecular mechanisms underlying TGF- $\beta$ mediated molecular responses, including cytostasis, during hepatocarcinogenesis.

Acknowledgements Serif Senturk is a recipient of the Young Scientists Award Program of the Turkish Academy of Sciences (TUBA GEBIP 2017) and the Science Academy's Young Scientist Awards Program (BAGEP 2019). The schematic for the canonical TGF- $\beta$ signaling cascade was created with BioRender.com. pSBE4-Luc was a gift from Bert Vogelstein (Addgene plasmid \# 16495) and p3TP-Lux was a gift from Joan Massague (Addgene plasmid \# 11767).

Author Contribution MZG and MU performed cell cycle experiments as well as BrdU incorporation assay and analyzed the data. The remaining experiments were carried out by SS. SS and MO conceived and designed the study and analyzed the data. MZG, MU, and SS all made substantial contributions to the preparation of the figures and drafting the manuscript. The final manuscript was read and approved by all authors.

\section{Declarations}

Conflict of Interest The authors declare no competing interests.

\section{References}

1. Globocan. "WHO Liver Cancer Fact Sheet". 2020.

2. Llovet JM et al. "Hepatocellular carcinoma," Nat Rev Dis Primer. 2021;7(1). https://doi.org/10.1038/s41572-020-00240-3.

3. Villanueva A. "Hepatocellular carcinoma," N Engl J Med. 2019;1450-1462. https://doi.org/10.1056/NEJMra1713263.

4. Llovet JM, Zucman-rossi J, Pikarsky E, Sangro B, Sherman M, Gores G. "Hepatocellular carcinoma," Nat. Rev. Dis. Primer. 2016;2. https:// doi.org/10.1038/nrdp.2016.18.

5. Zucman-rossi J, Villanueva A, Nault J, Llovet JM. Genetic landscape and biomarkers of hepatocellular carcinoma. YGAST. 2015;149(5):1226-1239.e4. https://doi.org/10.1053/j.gastro.2015. 05.061 .

6. Ozturk M, Arslan-Ergul A, Bagislar S, Senturk S, Yuzugullu H. Senescence and immortality in hepatocellular carcinoma. Cancer Lett. 2009;286(1):103-13. https://doi.org/10.1016/j.canlet.2008. 10.048 .

7. Yuzugullu $\mathrm{H}$ et al. Canonical Wnt signaling is antagonized by noncanonical Wnt5a in hepatocellular carcinoma cells. Mol Cancer. 2009;8:1-20. https://doi.org/10.1186/1476-4598-8-90.

8. Caruso $\mathrm{S}$ et al. "Analysis of liver cancer cell lines identifies agents with likely efficacy against hepatocellular carcinoma and markers of response," Gastroenterology. 2019;1-17. https://doi.org/10. 1053/j.gastro.2019.05.001.

9. Dituri F, Mancarella S, Cigliano A, Chieti A, Giannelli G. TGF- $\beta$ as multifaceted orchestrator in HCC progression: signaling, EMT, immune microenvironment, and novel therapeutic perspectives.
Semin Liver Dis. 2019;39(1):53-69. https://doi.org/10.1055/s0038-1676121.

10. Weiss A, Attisano L. The TGFbeta superfamily signaling pathway. WIREs Dev Biol. 2013;2:47-63. https://doi.org/10.1002/wdev.86.

11. Derynck R, Zhang YE. Smad-dependent and Smad-independent pathways in TGF- $\beta$ family signalling. Nature. 2003;425:577-84.

12. Zhang YE "Non-Smad signaling pathways of the TGF- $b$ family," Cold Spring Harb Perspect Biol. 2017;1-18.

13. Massagué J, Seoane J, Wotton D. Smad transcription factors. Genes Dev. 2005;19(23):2783-810. https://doi.org/10.1101/gad. 1350705.

14. Arrese M, Cabrera D, Hernandez A, Astete L, Estrada L. "TGF$\beta$ and hepatocellular carcinoma: when a friend becomes an enemy," Curr Protein Pept Sci. 2018;19. https://doi.org/10.2174/ 1389203718666171117112619.

15. Seoane J, Gomis RR. "TGF- b family signaling in tumor suppression and cancer progression," Cold Spring Harb Perspect Biol. 2017;9. https://doi.org/10.1101/cshperspect.a022277.

16. Dzieran J et al. Comparative analysis of TGF- $\beta$ / Smad signaling dependent cytostasis in human hepatocellular carcinoma cell lines. PLoS One. 2013;8(8):1-18. https://doi.org/10.1371/journal.pone. 0072252.

17. Hao Y, Baker D, Ten Dijke P. "TGF- $\beta$-mediated epithelialmesenchymal transition and cancer metastasis," Int J Mol Sci. 2019;20(11). https://doi.org/10.3390/ijms20112767.

18. Fabregat I, Caballero-Díaz D. "Transforming growth factor- $\beta$ induced cell plasticity in liver fibrosis and hepatocarcinogenesis," Front Oncol. 2018;8. https://doi.org/10.3389/fonc.2018.00357.

19. Senturk S, Mumcuoglu M, Gursoy-Yuzugullu O, Cingoz B, Akcali KC, Ozturk M. Transforming growth factor-beta induces senescence in hepatocellular carcinoma cells and inhibits tumor growth. Hepatology. 2010;52(3):966-74. https://doi.org/10.1002/ hep. 23769 .

20. Coulouarn C, Factor VM, Thorgeirsson SS. Transforming growth factor- $\beta$ gene expression signature in mouse hepatocytes predicts clinical outcome in human cancer. Hepatology. 2008;47(6):2059_ 67. https://doi.org/10.1038/jid.2014.371.

21. Huh N, Utakoji T. Production of HBs-antigen by two new human hepatoma cell lines and its enhancement by dexamethasone. Gan. 1981;72(1):178-9.

22. Park JG et al. Characterization of cell lines established from human hepatocellular carcinoma. Int J Cancer. 1995;62(3):27682. https://doi.org/10.1002/ijc.2910620308.

23. Hirschfield $\mathrm{H}$ et al. In vitro modeling of hepatocellular carcinoma molecular subtypes for anti-cancer drug assessment. Exp Mol Med. 2018;50(1): e419. https://doi.org/10.1038/emm.2017.164.

24. Heffelfinger SC, Hawkins HH, Barrish J, Taylor L, Darlington GJ. "SK HEP-1: a human cell line of endothelial origin", Vitro Cell. Dev Biol J Tissue Cult Assoc. 1992;28A(2):136-42. https://doi. org/10.1007/BF02631017.

25. Alexander JJ. "Human hepatoma cell lines," in Neoplasms of the liver, K. Okuda and K. G. Ishak, Eds. Tokyo: Springer Japan. 1987;47-56. https://doi.org/10.1007/978-4-431-68349-0_4.

26. He L, Isselbacher KJ, Wands JR, Goodman HM, Shih C, Quaroni A. Establishment and characterization of a new human hepatocellular carcinoma cell line. Vitro. 1984;20(6):493-504. https://doi. org/10.1007/BF02619623.

27. Inagaki M, Moustakas A, Lin HY, Lodish HF, Carr BI. Growth inhibition by transforming growth factor beta (TGF-beta) type I is restored in TGF-beta-resistant hepatoma cells after expression of TGF-beta receptor type II cDNA. Proc Natl Acad Sci USA. 1993;90(11):5359-63. https://doi.org/10.1073/pnas.90.11.5359.

28. Cerami E et al. The cBio Cancer Genomics Portal: an open platform for exploring multidimensional cancer genomics data. Cancer Discov. 2012;2(5):401-4. https://doi.org/10.1158/2159-8290. CD-12-0095. 
29. Tate JG et al. COSMIC: the Catalogue Of Somatic Mutations In Cancer. Nucleic Acids Res. 2019;47(D1):D941-7. https://doi.org/ 10.1093/nar/gky1015.

30. Barretina $\mathbf{J}$ et al. The Cancer Cell Line Encyclopedia enables predictive modelling of anticancer drug sensitivity. Nature. 2012;483(7391):603-7. https://doi.org/10.1038/nature11003.

31. Kitisin $\mathrm{K}$ et al. Disruption of transforming growth factor- $\mathrm{b}$ signaling through $\mathrm{b}$-spectrin ELF leads to hepatocellular cancer through cyclin D1 activation. Oncogene. 2007;26:7103-10. https://doi.org/ 10.1038/sj.onc.1210513.

32. Baek MJ et al. "p16 is a major inactivation target in hepatocellular carcinoma", Cancer no. Cdk. 2000;4:60-8.

33. Liew CT et al. High frequency of p16 INK4A gene alterations in hepatocellular carcinoma. Oncogene. 1999;18:789-95.

34. Tannapfel A et al. INK4a-ARF alterations and p53 mutations in hepatocellular carcinomas. Oncogene. 2001;20:7104-9.

35. Zang $\mathrm{J}$ et al. P16 gene hypermethylation and hepatocellular carcinoma : a systematic review and meta-analysis. World J Gastroenterol. 2011;17(25):3043-8. https://doi.org/10.3748/wjg.v17.i25. 3043.

36. Yarchoan $\mathrm{M}$ et al. "Recent developments and therapeutic strategies against hepatocellular carcinoma". 2019;79(17):43264331. https://doi.org/10.1158/0008-5472.CAN-19-0803.

37. Nault JC et al. Clinical impact of genomic diversity from early to advanced hepatocellular carcinoma. Hepatology. 2019;71:164-82. https://doi.org/10.1002/hep.30811.

38. Nagaraj NS, Datta PK. Targeting the transforming growth factor- $\beta$ signaling pathway in human cancer. Expert Opin Investig Drugs. 2010;19(1):77-91. https://doi.org/10.1517/13543780903382609.

39. Haque S, Morris JC. Transforming growth factor- $\beta$ : a therapeutic target for cancer. Hum Vaccines Immunother. 2017;13(8):174150. https://doi.org/10.1080/21645515.2017.1327107.

40. Caja L et al "Differential intracellular signalling induced by TGF$\beta$ in rat adult hepatocytes and hepatoma cells : implications in liver carcinogenesis". 2007;19:683-694. https://doi.org/10.1016/j. cellsig.2006.09.002.

41. Sanchez A, Alberto MA, Benito M, Fabregat I. Apoptosis induced by transforming growth factor- $\beta$ in fetal hepatocyte primary cultures. J Biol Chem. 1996;271(13):7416-22. https://doi.org/10. 1074/jbc.271.13.7416.

42. Kim DH, Kim WD, Kim SK, Moon DH, Lee SJ. "TGF- $\beta 1$ mediated repression of SLC7A11 drives vulnerability to GPX4 inhibition in hepatocellular carcinoma cells," Cell Death Dis. 2007;11(5). https://doi.org/10.1038/s41419-020-2618-6.

43. Jong $\mathrm{H}$ et al. Attenuation of transforming growth factor $\beta$-induced growth inhibition in human hepatocellular carcinoma cell lines by cyclin D1 overexpression. Biochem Biophys Res Commun. 2002;292:383-9. https://doi.org/10.1006/bbrc.2002.6666.

44. Yakicier MC, Irmak MB, Romano A, Kew M, Ozturk M. Smad2 and Smad4 gene mutations in hepatocellular carcinoma. Oncogene. 1999;18:4879-83. https://doi.org/10.1038/sj.onc.1202866.

45. Di Guglielmo GM, Le Roy C, Goodfellow AF, Wrana JL. "Distinct endocytic pathways regulate TGF- $\beta$ receptor signalling and turnover". Nat Cell Biol. 2003;5. https://doi.org/10.1038/ ncb975.

46. Mishra B et al. "Loss of cooperative function of transforming growth factor- $\mathrm{b}$ signaling proteins, smad 3 with embryonic liver fodrin, a b -spectrin, in primary biliary cirrhosis". 2004;(5)637645. https://doi.org/10.1111/j.1478-3231.2004.0958.x.

47. Dijke P, Miyazono K, Heldin C. Signaling inputs converge on nuclear effectors in TGF- $\beta$ signaling. Trends Biochem Sci. 2000;25(2):64-70. https://doi.org/10.1016/S0968-0004(99) 01519-4.

48. Vidakovic AT et al. Context-specific effects of TGF- $/$ /SMAD3 in cancer are modulated by the epigenome. Cell Rep. 2015;13:2480 90. https://doi.org/10.1016/j.celrep.2015.11.040.

49. Hill CS. "Transcriptional control by the SMADs," Cold Spring Harb Perspect Biol. 2016;8. https://doi.org/10.1101/cshperspect. a022079.

50. Kojima $\mathrm{T}$ et al. Transforming growth factor- $\beta$ induces epithelial to mesenchymal transition by down-regulation of claudinlexpression and the fence function in adult rat hepatocytes. Liver Int. 2008;28(4):534-45. https://doi.org/10.1111/j.1478-3231.2007. 01631.x.

51. Ohashi $\mathrm{S}$ et al. Epidermal growth factor receptor and mutant $\mathrm{p} 53$ expand an esophageal cellular subpopulation capable of epithelialto-mesenchymal transition through ZEB transcription factors. Cancer Res. 2010;70(10):4174-85. https://doi.org/10.1158/00085472.CAN-09-4614.

52. Postigo AA. Opposing functions of ZEB proteins in the regulation of the TGF $\beta / B M P$ signaling pathway. EMBO J. 2003;22(10):2443-52. https://doi.org/10.1093/emboj/cdg225.

53. Acun T, Oztas E, Yagci T, Yakicier MC. SIP1 is downregulated in hepatocellular carcinoma by promoter hypermethylation. BMC Cancer. 2011;11(1):223. https://doi.org/10.1186/ 1471-2407-11-223.

Publisher's Note Springer Nature remains neutral with regard to jurisdictional claims in published maps and institutional affiliations. 